\title{
Effect of Gamma Ray and Sodium Azide on the Germination, Survival and Morphology of Varieties of Okro
}

\section{(Abelmuscus esculantus L. moench)}

\author{
Ati, Hassana Maryam ${ }^{1 *}$ \\ ${ }^{1}$ Federal university Dutsin-ma. Katsina state.
}

Received: November 19, 2016; Accepted: January 26, 2017; Published: June 8, 2017

*Corresponding author: Hassana Maryam, Department of Crop Production and Protection, Federal university Dutsin-ma. Katsina state. E-Mail: ahassana@fudutsinma.edu.ng

\begin{abstract}
Okro, Abelmoschus esculantusL. Moench is an important medicinal herb of the family Malvaceae. The oil is used in various pharmaceutical industries due to its high medicinal properties. Three varieties of okro seeds: Jokoso, NHAe47-4 and a local variety (Beru) were exposed to varying concentrations of sodium azide (NaN3) in the range of $1.0 \mathrm{mM}$ to $4.0 \mathrm{mM}$ and gamma rays 60 Co doses in the range $20-100 \mathrm{kR}$ respectively. Morphological traits of the genotypes were measured according to the coding criteria specified by the Standard International Crop Descriptor for okro. Variations in the percentage germination, survival, seedling height, stem height; leaf length and the fruit length were recorded. There were significant differences between the control and the treated seeds in all the characters considered. Effect of the mutagenic treatments resulted in decreasing percentage germination, survival, and average stem height, Leave length and fruit length with increase in concentration and doses of the mutagens. The effective concentration of sodium azide solution for okro seeds are: $1.0 \mathrm{mM}, 2.0 \mathrm{mM}, 3.0 \mathrm{mM}$, and $4.0 \mathrm{mM}$. While the effective doses of Gamma rays for okro seeds are $20 \mathrm{kR}, 40 \mathrm{kR}$, and $60 \mathrm{kR}$ for the varieties used in this research. All the three varieties responded similarly to the concentrations of Sodium azide. Sodium azide and gamma rays can be used for inducing mutation that will produce genetic variability in Okro.
\end{abstract}

Key Words: Concentrations; Agronomic Characters; Genotypes; Mutagenic Treatments;

\section{Introduction}

Mutation is a sudden heritable change in an organism. Which may be structural or functional, but generally structural changes occur. It is produced by changes in base sequence of gene and it can be spontaneously or artificially both in seed and vegetative propagated crops. But seed is the most commonly used material for mutational studies because it can tolerate physical conditions.

Induced mutation has been established as an important tool for improvement of certain traits in the existing germplasm. Mutations are of two type viz., natural and artificial or induced mutation. Frequency of natural mutation is very low and hence, artificial mutation with application of mutagens is followed to get better genetic variability. Various types' of chemicals capable of inducing mutation in plants had been found out. They are Ethyl Methane Sulphonate (EMS), Methyl Methane Sulphonate (MMS), diethylsulphate (DES), Ethylene Imine (EI), Hydroxyl Amine(HA), n-nitroso-n-ethyl urea (NEU), Nitrous Acid(NA), sulphur mustard, 5-bromouracil, Sodium Azide (SA) etc. [5].

Considerable progress has been made on induce mutations of okro [Abelmoskhusesulentus (L.)Moench] for improvement of their certain characters, but detailed studies are lacking. Traits like germination, pollen sterility, plant length, fruit length, survival to maturity and mortality are much affected by mutagenic treatment. Therefore, an attempt has been made to study the effect of mutagenic treatment on agronomic characters of okro. Induced mutations have recently become the subject of biotechnology and molecular investigation leading to description of the structure and function of related genes. Induced mutation in plant is an effective tool for crop improvement [1].

The mutagenic effects of sodium azide have been documented in previous reports. [6] Reported that sodium azide is a very potent mutagen in barley and induced chlorophyll deficiency as well as a wide range of morphological and physiological mutants and [3] reported that gamma ray mutagenesis can be expected to yield severe phenotypic high proportion of useful mutations with normal yielding properties. In plant cells; the nucleus is considered the principal site of damage by ionizing radiation [1].

\section{Materials and Methods \\ Plant Source and Mutagen Treatment}

Two improved varieties ( Table ) of Okro, Abemuscusesculatus L. Moench seeds were collected from Institute of Agricultural Research (Plant science department) and a local variety was purchased in Sabo main market Zaria and taken to Centre for Energy Research and Development, ObafemiAwolowo University Ile-ife $\left(7^{\circ} 28^{\prime} \mathrm{N}\right.$ and $\left.4^{\circ} 32^{\prime} \mathrm{E}\right)$ for radiation with Gamma cell 220 Cobalt $60\left(\mathrm{Co}^{60}\right)$ part of the seeds were treated with Sodium azide 
in the laboratory in Biological Sciences department, Ahmadu Bello University (A.B.U.), Zaria.(11 ${ }^{\circ} 04^{\prime} \mathrm{N}$ and $\left.7^{\circ} 42^{\prime} \mathrm{E}\right)$ The Sodium azide used for this research was collected from Biochemistry department A.B.U. zaria.

\begin{tabular}{|c|c|c|c|}
\hline \multicolumn{2}{|c|}{ Table: } & Description & Source \\
\hline S/No & Genotypes & Local variety & Local market \\
\hline 1 & Beru & Improved variety & $\begin{array}{c}\text { Institute of } \\
\text { Agricultural } \\
\text { Research, Zaria }\end{array}$ \\
\hline 2 & Jokoso & Improved variety & $\begin{array}{c}\text { Institute of } \\
\text { Agricultural } \\
\text { Research, Zaria }\end{array}$ \\
\hline 3 & NHAe47-4 & & \\
\hline
\end{tabular}

\section{Planting of the Seeds}

The experiment was categorized into two treatment groups. I.e. sodium azide and gamma rays. In first category, seeds were presoaked in buffer solution for two hours then soaked in sodium azide solutions of $1.0 \mathrm{mM}, 2.0 \mathrm{mM}, 3.0 \mathrm{mM}$ and $4.0 \mathrm{mM}$ for one hour after which the treated seeds were washed in tap water to remove excess chemicals and exudates from the seeds and in second category; 20,40,60,80 and $100 \mathrm{kR}$ doses of gamma rays using Co60 as a source in gamma chamber. The seeds were observed daily until maximum germination was achieved. Planting of sets of seeds treated Sadium Azide, those treated with Gamma ray and the control seeds were done in Botanical garden, Ahmadu Bello University Zaria, using the open garden to study the effect of the two mutagens on each set of okro seeds. Each plot consisted of five rows and each row was four meters long with the intra row spacing of $50 \mathrm{~cm}$ and inter row spacing of $75 \mathrm{~cm}$ apart in three replications. Eight hills of two seeds each were planted per row. The layout follows $3 \times 5$ Randomized Complete Block Design (RCBD).

\section{Data Collection}

The growth of plant was estimated in relation to the time of flowering, maturity and variability in plant development within and between treatments. The following data were collected: percentage germination, seedling height, and leaf length, survival at maturity, fruit length and height at maturity.

\section{Statistical Analysis}

The data collected were subjected to the following statistical methods for analyzing the data: Mean (average) percentages, analysis of variance (ANOVA) and t-test was used to determine if there was any significant difference between the two mutagens.

\section{Results and Discussion}

The T-Test Between The Two Mutagens Shows There Is Significant Difference In The Leave Length And Fruit Length For Nhae47-4. There Was No Significant Difference Between The Effects Of The Two Mutagens For The Other Parameters Of The Nhae47-4. Also, There Was No Significant Difference Between The Effects Of The Two Mutagens For The All Parameters Of Beru And Jokoso (Table 1). This Shows That The Two Mutagens Have Similar Effect On The Okro Varieties. This Is In Line With the Work Of [1].

Table 1: Result of t-test between Gamma ray and Sodium azide for all the varieties

\begin{tabular}{|c|c|c|c|c|}
\hline $\begin{array}{c}\text { Variety } \\
\text { length }\end{array}$ & $\begin{array}{c}\text { Seedling } \\
\text { Height }\end{array}$ & $\begin{array}{c}\text { Stem } \\
\text { Height }\end{array}$ & $\begin{array}{c}\text { Leave } \\
\text { length }\end{array}$ & Fruit \\
\hline Beru & 0.376808 & 1.066381 & 1.023216 & 0.309004 \\
\hline Jokoso & 1.408269 & 0.369527 & 0.093874 & -0.14275 \\
\hline NHAe47-4 & -0.03261 & 2.652084 & $2.389943^{*}$ & $4.834658^{*}$ \\
\hline \multicolumn{5}{|c|}{ * Significant at the 5\% level of probability } \\
\end{tabular}

The present investigation revealed that the germination and survival percentages of the three varieties of okro seeds decrease with increasing concentrations of two mutagens. Reductions in germination and survival percentages due to the effect of mutagens on various crop plants have earlier been documented by $[9$, 10].

It was estimated that for all the three varieties, germination $\%$ ranges from $80 \%$ to $95 \%$ observed at $1 \mathrm{Mm}$ to $4 \mathrm{mM}$ of sodiumazide and $20 \%$ to $75 \%$ at 20 to $100 \mathrm{kR}$ of gamma rays. (Tables 2-4). The impact and tolerance of the biological material to the mutagens were marked in all the three varieties in terms of germination and seedling survival. This observation remained in parity with $[11,1,5]$. In this investigation, germination percentage, seedling height, average plant height, leaf length and fruit length decreases with increasing dose/concentration (Table 2- 4) and the viable mutants observed could be used as a dependable measure of genetic effect of mutagen. The maximum viable mutants were observed in chemical mutagen (sodium azide) while, minimum in physical mutagen (Gamma rays) shown in (Table $2-4)$. Similar results were also reported by $[7,4]$ in okro.

The seedling height, average plant height, leaf length and fruit length in different treatments showed significant reductions in the higher doses of the mutagens. The results revealed that the most efficient concentration for inducing mutations in the three varieties using sodium azide is 1, 2 and $3 \mathrm{Mm}$ and 20, 40 and 60 kR for gamma rays. [8] Reported that the effectively of gamma rays induced mutations in okro cv. selection 2-2 with gamma irradiation ranges between 10 to $60 \mathrm{kR}$. Also [1] reported that Mutagen $(0.80 \mathrm{kR}$. and $0.20 \%)$ significantly produced more branches, more buds and number of fruits/plants than the control plants. [2] Reported similar results in Trigonellafoenumfraeum. 
Table 2: Effect of Sodium Azide (SA) and Gamma Rays (GR) on agronomic characters of Beru Variety (Mean Length in centimeter)

\begin{tabular}{|c|c|c|c|c|c|}
\hline Mutagen & $\begin{array}{c}\text { Percentage (\%) } \\
\text { Germination }\end{array}$ & Seedling Height & Stem Height at Maturity & Leaf Length & Fruit Length \\
\hline Control & $97 a$ & $9.5 \mathrm{a}$ & $28.00 \mathrm{a}$ & $10.50 \mathrm{a}$ & $5.60 \mathrm{a}$ \\
\hline $\begin{array}{c}\text { Gamma Ray } \\
20 \mathrm{Kr}\end{array}$ & $65 a$ & $8.5 b$ & $25.17 \mathrm{a}$ & $8.92 a$ & $4.80 \mathrm{a}$ \\
\hline $\begin{array}{c}\text { Gamma Ray } \\
40 \mathrm{Kr}\end{array}$ & $75 a$ & $8.6 \mathrm{~b}$ & $21.13 b$ & $6.25 b$ & $4.90 \mathrm{a}$ \\
\hline $\begin{array}{c}\text { Gamma Ray } \\
\quad 60 \mathrm{Kr}\end{array}$ & $75 a$ & $7.2 \mathrm{~b}$ & $14.67 \mathrm{c}$ & $6.50 \mathrm{~b}$ & $4.36 \mathrm{a}$ \\
\hline $\begin{array}{c}\text { Gamma Ray } \\
100 \mathrm{Kr}\end{array}$ & $50 \mathrm{~b}$ & $4.8 \mathrm{c}$ & $5.67 d$ & $1.92 \mathrm{c}$ & - \\
\hline SodiumAzide 1.0 & $96 a$ & $7.4 \mathrm{~b}$ & - & - & - \\
\hline SodiumAzide 2.0 & $95 a$ & 9.8 & $12.75 \mathrm{c}$ & $5.80 \mathrm{~b}$ & $6.00 \mathrm{a}$ \\
\hline Sodium Azide 3.0 & $95 a$ & $2.4 \mathrm{~d}$ & $13.25 \mathrm{c}$ & $5.40 \mathrm{~b}$ & $3.83 \mathrm{~b}$ \\
\hline Sodium Azide 4.0 & $90 \mathrm{a}$ & $6.5 c$ & $10.50 \mathrm{c}$ & $5.90 \mathrm{~b}$ & $3.50 \mathrm{~b}$ \\
\hline
\end{tabular}

Table 3: Effect of Sodium Azide (SA) and Gamma Rays (GR) on some agronomic characters of Jokoso Variety (Mean in Centimeter)

\begin{tabular}{|c|c|c|c|c|c|}
\hline Mutagen & $\begin{array}{c}\text { Percentage (\%) } \\
\text { Germination }\end{array}$ & Seedling Height & $\begin{array}{c}\text { Stem Height at } \\
\text { Maturity }\end{array}$ & Leaf Length & Fruit Length \\
\hline Control & $96 a$ & $6.70 \mathrm{a}$ & $21.00 \mathrm{a}$ & $10.00 \mathrm{a}$ & $7.60 \mathrm{a}$ \\
\hline $\begin{array}{c}\text { Gamma Ray } \\
20 \mathrm{Kr}\end{array}$ & $40 \mathrm{~b}$ & $6.8 \mathrm{a}$ & $14.80 \mathrm{~b}$ & $8.42 \mathrm{a}$ & $6.0 \mathrm{~b}$ \\
\hline $\begin{array}{c}\text { Gamma Ray } \\
40 \mathrm{Kr}\end{array}$ & $55 \mathrm{a}$ & $6.4 \mathrm{a}$ & $11.91 b$ & $6.25 b$ & $3.25 \mathrm{~d}$ \\
\hline $\begin{array}{c}\text { Gamma Ray } \\
60 \mathrm{Kr}\end{array}$ & $40 \mathrm{~b}$ & $6.4 \mathrm{a}$ & $9.67 \mathrm{c}$ & $4.67 \mathrm{c}$ & - \\
\hline $\begin{array}{c}\text { Gamma Ray } \\
100 \mathrm{Kr}\end{array}$ & $20 \mathrm{~b}$ & $2.7 \mathrm{~b}$ & Died & - & - \\
\hline SodiumAzide 1.0 & $85 a$ & $5.2 \mathrm{~b}$ & $12.17 \mathrm{~b}$ & $5.40 \mathrm{~b}$ & $5.50 \mathrm{~b}$ \\
\hline SodiumAzide 2.0 & $85 a$ & $3.8 \mathrm{~b}$ & $9.17 \mathrm{c}$ & $6.40 \mathrm{~b}$ & $4.30 \mathrm{c}$ \\
\hline Sodium Azide 3.0 & $80 a$ & $5.2 \mathrm{~b}$ & $14.00 \mathrm{~b}$ & $9.50 \mathrm{a}$ & $5.13 b$ \\
\hline Sodium Azide 4.0 & $80 a$ & $2.8 \mathrm{~b}$ & $11.00 \mathrm{c}$ & $5.60 \mathrm{~b}$ & $4.50 \mathrm{c}$ \\
\hline
\end{tabular}


Table 4: Effect of Sodium Azide (SA) and Gamma Rays (GR) on some agronomic characters of NHAe47-4 (Mean in Centimeter)

\begin{tabular}{|c|c|c|c|c|c|}
\hline Mutagen & $\begin{array}{c}\text { Percentage (\%) } \\
\text { Germination }\end{array}$ & Seedling Height & $\begin{array}{c}\text { Stem Height at } \\
\text { Maturity }\end{array}$ & Leaf Length & Fruit Length \\
\hline Control & $95 a$ & $9.10 \mathrm{~b}$ & $24.00 \mathrm{a}$ & $9.80 \mathrm{a}$ & $5.70 \mathrm{a}$ \\
\hline $\begin{array}{c}\text { Gamma Ray } \\
20 \mathrm{Kr}\end{array}$ & $40 \mathrm{~b}$ & $6.50 \mathrm{~d}$ & $21.75 b$ & $9.83 a$ & $5.70 \mathrm{a}$ \\
\hline $\begin{array}{c}\text { Gamma Ray } \\
40 \mathrm{Kr}\end{array}$ & $50 a$ & $5.40 \mathrm{e}$ & $16.33 c$ & $6.83 b$ & $5.30 \mathrm{a}$ \\
\hline $\begin{array}{c}\text { Gamma Ray } \\
60 \mathrm{Kr}\end{array}$ & $65 a$ & $5.60 \mathrm{~d}$ & $11.83 \mathrm{~d}$ & $8.58 \mathrm{a}$ & $4.75 a$ \\
\hline $\begin{array}{c}\text { Gamma Ray } \\
100 \mathrm{Kr}\end{array}$ & $35 b$ & $3.70 \mathrm{f}$ & $5.00 \mathrm{f}$ & - & - \\
\hline SodiumAzide 1.0 & $95 a$ & $4.90 \mathrm{e}$ & $9.50 \mathrm{e}$ & $3.80 \mathrm{c}$ & $3.50 \mathrm{~b}$ \\
\hline SodiumAzide 2.0 & $95 a$ & $11.00 \mathrm{a}$ & $9.25 \mathrm{e}$ & $4.70 \mathrm{c}$ & $3.63 b$ \\
\hline Sodium Azide 3.0 & $80 \mathrm{a}$ & $2.80 \mathrm{f}$ & $8.50 \mathrm{e}$ & $3.40 \mathrm{c}$ & $3.00 \mathrm{~b}$ \\
\hline Sodium Azide 4.0 & $80 a$ & $2.00 \mathrm{~g}$ & - & - & - \\
\hline
\end{tabular}

\section{Summary and Conclusion}

The outcomes of this research revealed that the most efficient concentrations for inducing mutations in the three varieties using sodium azide are: 1, 2 and $3 \mathrm{Mm}$ and 20, 40 and $60 \mathrm{kR}$ for gamma rays.

None of the mutants performed better than the control except in Beru variety where $2 \mathrm{Mm}$ of sodium Azide produces longer seedling height and fruit length $(9.8 \mathrm{~cm}$ and $6.0 \mathrm{~cm}$ respectively). Hence the doses and concentrations of the mutagens induce variable mutations on the Okro varieties used in this research.

\section{References}

1. Ashish R., Nandkishor H R, and Prashant W. Effect of Sodium Azide and Gamma Rays Treatments on Percentage Germination, Survival, Morphological Variation and Chlorophyll Mutation in Musk Okro (AbelmoschusMoschatus L.). International Journal of Pharmacy and Pharmaceutical Sciences. 2011;3(5): ISSN- 0975-1491.

2. Biswas AK, Datta AK. Induced mutation in two Trigonella species. Banglad J. Bot. 1988;17:211-214

3. Froicer K. Aspects of the agriculture value of certain barley x-ray mutations produced and tested at the Swedish Seed Association, Svalof, and its branch stations. Acta Agric. Scand. 1954;4:515-517.

4. Ghai T R, Singh M, Arora S K. Induced variability for economic characters in okro. J. Res. Punjab Agric. Univ. 2004;41:63-67.
5. Jadhav P A, Kalpande H V, Kathale M N, Dahale G P. Effect of gamma rays and ethyl methane sulphonate on germination, pollen viability and survival of okro [Abelmoschusesculentus (L.) Moench]. Journal of Crop and Weed. 2012;8(2):130-131.

6. Kleinhofs AW, Owais M, Nilan RA. Azide. Mutation Research. 1978;55:165-195.

7. Kumar A, Mishra M N. Effect of gamma rays EMS and NMU on germination, seedlingvigour, pollen viability and plant survival in M1 and M2 generations of okro. Adv. Pl. Sci. 2004;17:295-97.

8. Malani S S, Kale P B, Gonge V S. Effectivity of gamma rays induced mutations in okro. PKV Res. J. 1993;17:1-5.

9. Mensah JK, Akomeah PA, Ekpekurede EO. Gamma irradiation induced variation of yield parameters in cowpea (Vignaunguiculata (L.) Walp.) Global J. Pure Appl. Sci. 2005;11(3):327-330.

10. Mensah JK, Akomeah PA. Mutagenic effects of hydroxylamine and streptomycin on the growth and seed yield of the cowpea, Vigna Unguiculata (L.) Walp. Legume Res. 1997;15:39-44.

11. Singh A K, Singh K P (2000). Seedling injury, reduced pollen and ovule fertility and chlorophyll mutations induced by gamma rays and EMS in okro. Veg. Sci., 27: 42-44. 